\begin{tabular}{l|l} 
Potaice & e-ISSN: 2655-9404 p-ISSN: 2721-8376 \\
Vol. 5 No. 1, Februari 2022 & DOI: 10.20473/ntr.v5i1.33073 \\
\hline
\end{tabular}

Article history: Submitted 20 January 2022; Accepted 7 February 2022; Available online 24 February 2022.

\title{
Kebijakan Pemberian Hak Guna Usaha Di Atas Hak Pengelolaan Dalam Perspektif Undang-Undang Pokok Agraria
}

\author{
Aditya Darmawan Zakaria \\ adityazakaria1997@gmail.com \\ Universitas Airlangga
}

\begin{abstract}
issues related to usufructuary rights in Indonesia can be given above management rights. This provision contradicts Article 28 of the LoGA which requires that HGU can only be granted on state land. So that we need a policy that provides legal certainty and convenience in providing services and certificates that obtain land rights, namely cultivation rights over management rights. based on the applicable laws, Government Regulation Number 18 of 2021 concerning Management Rights, Land Rights, Flat Units and Land Registration, Government Regulation Number 24 of 1997 concerning Land Registration and the Basic Agrarian Law. The results of the study provide an explanation of the policy on granting rights to cooperation with cultivation rights before PP number 18 of 2021. The agreement is in the form of written approval from the HPL holder, which is a type of cooperation as outlined in the agreement and the transfer of land rights to become development land. The existence of disharmony between Article 21 of PP 18 of 2021 and Article 28 of the UUPA has led to the application of the Lex Superiori Derogat Legi Inferiori principle which results in legal uncertainty and has the potential to be subject to judicial review by the Supreme Court.

Keywords: Land Rights; Management Rights; Cultivation Rights; State Land.
\end{abstract}

\begin{abstract}
Abstrak
isu terkait hak guna usaha di Indonesia dapat diberikan di atas hak pengelolaan. Ketentuan tersebut bertentangan dengan Pasal 28 UUPA yang mengharuskan HGU hanya bisa diberikan di atas tanah negara. Sehingga diperlukan kebijakan yang memberikan kepastian hukum serta kemudahan dalam pemberian pelayanan maupun sertipikat yang memperoleh hak atas tanah yaitu hak guna usaha di atas hak pengelolaan.Tujuan penelitian ini adalah menganalisa kebijakan terkait Pemberian Hak Guna Usaha di ataas Hak Pengelolaan, melalui pendekatan yuridis normatif yaitu peraturan berdasarkan perundang-undangan yang berlaku Peraturan Pemerintah Nomor 18 Tahun 2021 tentang Hak Pengelolaan, Hak Atas Tanah, Satuan Rumah Susun serta Pendaftaran Tanah, Peraturan Pemerintah Nomor 24 Tahun 1997 mengenai Pendaftaran Tanah dan Undang-Undang Pokok Agraria. Hasil telaah memberikan penjelasan kebijakan pemberian dari hak atas kerja sama hak guna usaha sebelum PP nomor 18 tahun 2021 Perjanjian berbentuk persetujuan tertulisd dari pemegang HPL, merupakan macam Kerjasama yang dituangkan dalam perjanjian dan peralihan hak atas tanah guna menjadi lahan pembangunan. Adanya disharmonisasi antara pasal 21 PP 18 tahun 2021 dengan pasal 28 UUPA menyebabkan berlakunya asas Lex Superiori Derogat Legi Inferiori yang berakibat ketidakpastian hukum dan berpotensi dilakukan uji materi oleh Mahkamah Agung.
\end{abstract}

Kata Kunci: Hak Atas Tanah; Hak Pengelolaan; Hak Guna Usaha; Tanah Negara. 


\section{Pendahuluan}

Salah satu yang menjadi faktor penting dalam kehidupan masyarakat Indonesia adalah tanah. Sebab sebagian besar penduduk di Indonesia menggantungkan hidupnya dari tanah. Sejak lahir manusia membutuhkan tanah sebagai salah satu kebutuhan dasar, ia dapat dijadikan sebagai lahan usaha pertanian, kegiatan sosial, bahkan tempat tinggal. ${ }^{1}$ Tanah merupakan modal utama untuk melaksanakan pembangunan nasional, ia dapat digunakan untuk meningkatkan pendapatan nasional melalui komoditas perdagangan yang dihasilkan. ${ }^{2}$ Dalam proses pembangunan nasional kedudukan tanah telah tercantum dalam ketetapan MPR sebagai berikut: ${ }^{3}$

"Penataan penguasaan tanah oleh negara diarahkan pemanfaatannya dapat mewujudkan keadilan sosial bagi seluruh rakyat Indonesia, sedangkan penataan penggunaan tanah dilaksanakan secara berencana guna mewujudkan kemakmuran rakyat yang sebesar-besarnya. Penataan penggunaan tanah perlu memperhatikan hakhak rakyat atas tanah, fungsi sosial hak atas tanah, batas maksimum pemilikan tanah, termasuk berbagai upaya untuk mencegah pemusatan penguasaan tanah yang merugikan kepentingan rakyat. Kelembagaan pertanahan disempurnakan agar makin terwujud sistem pengelolaan pertanahan yang terpadu, serasi, efektif, efisien, yang meliputi tertib administrasi hidup. Kegiatan pengembangan administrasi pertanahan perlu ditigkatkan dan ditunjang dengan perangkat analisis dan perangkat informasi pertanahan yang makin baik".

Ketetapan tersebut selaras dengan amanat konstitusi $^{4}$ yang dijadikan sebagai tumpuan UUPA memastikan akan memberikan kesempatan untuk negara guna memberikan kepada perorangan serta badan hukum suatu hak atas tanah yang disesuaikan dengan kebermanfaatannya. Dengan seperti itu, pemilikan serta penguasaan tanah yang melewati batasan dari ketentuan yang telah diatur secara jelas menggambarkan tentang yang melawan asas yang telah ditetapkan. Program landreform yang bermaksud guna menciptakan kesamarataan sosial berbentuk pemerataan penguasaan tanah. ${ }^{5}$ Adapun maksimal besar serta jumlah

\footnotetext{
${ }^{1}$ Sri Hajati et al, Politik Hukum Pertanahan Indonesia (Airlangga University Press 2021).[1]

2 ibid.[2].

${ }^{3}$ TAP MPR RI No. II/MPR/1993 tentang GBHN.

${ }^{4}$ Pasal 33 Ayat (3) Undang- Undang Dasar Negara Republik Indonesia Tahun 1945.

${ }^{5}$ Sebagaimana dipaparkan oleh Pasal 7 serta Pasal 17 UUPA.
} 
tanah perumahan serta pembangunan yang lain dan penerapan berikutnya diatur lebih rinci dengan Peraturan Pemerintah. ${ }^{6}$ Dalam penjelasan Pasal 12 dikatakan, jika karna pembatasan perihal tanah- tanah guna perumahan dipandang kurang berarti ketimbang dengan tanah- tanah pertanian sebab tidak menyangkut banyak orang maka tentang ini bakal diatur dengan Peraturan Pemerintah.

Semenjak dini, ${ }^{7}$ UU Cipta kerja (UU CK) dibuat guna sebagai dorongan positif untuk kenaikan serta perkembangan laju ekonomi nasional yang aktif, dengan begitu maka lapangan pekerjaan akan terbuka seluas-luasnya. Tata cara pemerintah dan juga berbagai inovasi dalam mewujudkan peluang pemodalan dari luar negeri tergambar jelas dalam UU CK, hal tersebut dapat dilihat melalui pemangkasan birokrasi maupun penyederhanaan izin yang ada di Indonesia. Dalam UU CK beberapa ketentuan pun telah dicabut dan juga direvisi. Salah satunya ialah Peraturan Pemerintah mengenai: "Hak Pengelolaan, Hak Atas Tanah, Satuan Rumah Susun dan Pendaftaran Tanah" ${ }^{8}$

Lalu apa sebenarnya politik hukum dari adanya Peraturan Pemerintah tersebut? Menurut Mahfud M.D, politik hukum merupakan pembangunan hukum yang meliputi pembaharuan maupun pembentukan hukum yang disesuaikan dengan kebutuhan. Dalam hal implementasi, dilakukan pembinaan terhadap aparat penegak hukum maupun penegasan fungsi dari suatu lembaga dalam ketentuan hukum yang sudah ada. ${ }^{9}$ Dalam pembentukan peraturan perundangundangan, Indonesia tentunya tidak dapat terlepas dari politik hukum, sebab ia merupakan rechtstaat. Politik hukum dapat diklasifikasikan sebagai legal policy yang berkaitan dengan hukum yang berlaku atau hukum yang tidak diberlakukan. ${ }^{10}$ $56 / 1960$.

${ }^{6}$ UU No. 56/1960 mengenai Penetapan Besar Tanah Pertanian. Dalam Pasal 12 UU No.

7 Pada 2 Februari Tahun 2021, pemerintah sudah menerbitkan 49 peraturan pelaksana Undang- Undang No 11 Tahun 2020 mengenai Cipta Kerja, yang terdiri dari 45 Peraturan Pemerintah serta 4 Peraturan Kepala negara.

${ }^{8}$ Guna melaksanakan ketentuan Pasal 142 dan Pasal 185 huruf b maka disusunlah PP No.18/2021 tentang Hak Pengelolaan, Hak Atas Tanah, Satuan Rumah Susun dan Pendaftaran Tanah.

${ }^{9}$ Mahfud Md, Politik Hukum Di Indonesia (Raja Grafindo Persada 2011).[9].

${ }^{10}$ ibid. 
Guna terciptanya aturan yang memberikan pengayoman, perlakuan adil serta melindungi hak rakyat, maka perlu ketentuan dasar dalam proses pembentukan peraturan perundang- undangan, berlaku seperti ketentuan penting yang berlaku guna membuat peraturan dari cara dini pembentukannya hingga dengan peraturan itu diberlakukan pada masyarakat. hingga dengan adanya ketentuan yang utama hingga masing-masing pembuatan aturan tersebut dapat dilakukan dengan cara serta aturan cara yang pasti, dasar, serta standar yang mengikat seluruh badan yang berhak menciptakan peraturan perundangunangan, dengan sedemikian itu peraturan itu bisa bermaknsa dapat memenuhi kepentingan warga negara Indonesia atas peraturan perundang- undangan yang baik.

PP 18/2021 dibentuk untuk memadukan, mensinkronkan, menginovasi, serta mengganti ketentuan yang tidak selaras dari UU CK. ${ }^{11}$ PP 18/2021 hendak digunakan Pemerintah untuk menata secara jelas ketentuan UU CK melalui peraturan politisyang diberlakukan secara nasional. Hal tersebut dilakukan melalui penguatan konsep hak yang melekat pada tanah ${ }^{12}$ dalam program percepatan Pendaftaran Tanah berlandas digital yang dibentuk untuk menanggulangi bermacam halangan serta tantangan birokrasi serta regulasi yang melambatkan perkembangan iklim ekonomi serta bidang usaha di Indonesia.

Isu terkait tanah menjadi salah satu hal yang penting untuk diperbincangkan pada saat ini terlebih tanah ialah hal pokok yang sangat berguna untuk kehidupan. Kendati demikian isu yang beredar cukup beragam, yang terjadi di lingkungan bisnis sekitar kita, contohnya isu terkait pemberian HGU di atas hak pengelolaan. Ketentuan tersebut bertentangan dengan UUPA yang mengharuskan HGU hanya bisa diberikan di atas tanah negara. Selain itu terdapat isu tentang pengaturan hak pengelolaan yang diberikan di atas tanah hak ulayat pengaturan tersebut jelas bertentangan dengan prinsip yang ada di dalam hak pengelolaan itu sendiri, bahwa

\footnotetext{
${ }^{11}$ antara lain Peraturan Pemerintah No 40 Tahun 1996 mengenai Hak Guna Usaha, Hak Guna Bangunan serta Hak Pakai Atas Tanah, Peraturan Pemerintah No 24 Tahun 1997 tentang Pendaftaran Tanah, serta Peraturan Pemerintah No 103 Tahun 2015 mengenai Pemilikan Rumah.

${ }^{12}$ Hak yang melekat pada tanah meliputi: mengenai Hak Pengelolaan, Hak Atas Tanah, Dasar Rumah Susun, pemberian hak pada Ruang Atas Tanah serta Ruang Bawah Tanah, tercantum.
} 
hak pengelolaan adalah hak menguasai dari negara yang pelaksanaan kewenangannya sebagian dilimpahkan kepada pemegang haknya.

Hak Pengelolaan berdasar atas wewenang guna melaksanakan beberapa konsep yang berdasar pada hak atas tanah yang dikuasai negara yang berdasarkan ketentuan tersebut nantinya akan dilimpahkan pada kepada Institusi Pemerintah ataupun Badan Hukum yang memegang Hak Pengelolaan. ${ }^{13}$ Pelimpahan wewenang itu merupakan wewenang guna merancang pemanfaatan tanah yang berhubungan serta memilih Badan Hukum yang sesuai peruntukannya dalam memanfaatkannya ataupun subyek hukum yang telah diberi hak untuk memanfaatkannya dengan suatu hak atas tanah yang jarang ditentukan namun sangat penting dalam pengendalian konsep menguasai negara sesuai UUPA, misalnya Hak Guna Usaha.

Melihat konsep di atas, maka seluruh ketentuan-ketentuan tentang Hak Guna Usaha pada umumnya yang terdapat di ketentuan berlaku juga untukhak tanah yakni Hak Guna Usaha yang diberi Hak Pengelolaan melalui aturan jika selama dalam hal penggunaan dan pemanfaatan tiap pemegang Hak Guna Usaha, berlaku pula pada pemegang Hak Guna Usaha yang pertama kali memperolehnya bersumber pada akad perolehan penegang hak pengelolaan atas pemakaian tanah ataupun yang setelah itu mendapatkan Hak Guna Usaha itu berasal dari akad pemegang Hak Guna Usaha yang pertama, syarat pemakaian tanah yang mengkiat didetetapkan berdasarkan akad pemberian izin menggunakan tanah antara pemegang hak guna usaha pertama dengan pemegang Hak Pengelolaan di dalam akad yang akan datang. ${ }^{14}$

Suatu bukti di atas menunjukkan bahwa pelaksanaan pemberian Hak Pengelolaan itu sendiri sudah beralih dari bersifat publik yang terkandung dalam konsep dari Hak atas tanah dikuasai Negara ke yang bersifat lebih mengutamakan keuntungan semata namun bersifat privat atau provit dalam setiap akadnya, sebaliknya konsep Hukum Tanah Nasional yang kita harapkan dan dicitakan dalam UUPA merupakan bersumber

\footnotetext{
${ }^{13}$ Menurut Surat keputusan Menteri pertanahan negara agraria atau Kepala BPN yang disahkan pada tanggal 17 September No. 630. 1. 3433 tahun 1998 mengenai jaminan sertifikat yang diberikan dimana masih ada Hak Pengelolaan di atasnya.

14 Triadi Kurniawan, ‘Jurnal Fakultas Hukum Universitas Tulang Bawang' (2020) 18 Jurnal Keadilan Fakultas Hukum Universitas Tulang Bawang.[73].
} 
pada konsepsi tabiat hukum adat yang komunalistik religius, sebagaimana diharapkan dalam kemampuan privat tengah terdapat komponen kebersamaan. ${ }^{15}$

Fokus utama kajian penelitian ini yakni mengenai pemerintah daerah yang menguasai hak pengelolaan atas tanah negara serta yang telah dialihkan pada pihak ketiga melalui ketentuan dalam pemberian Akta Hak Guna Usaha yakni dampak hukum yang timbul pada penerapan dalam setiap akad peralihan Hak Guna Usaha yang di atasnya ada hak pengelolaan, serta rancangan serta aplikasi hukum yang proporsional serta saling menguntungkan dalam rangka upaya yang dilakukan untuk melakukan pengaturan Peralihan pemerintah daerah mengalihkan pada Pihak Ketiga sebagai pengelola dengan memberikan sertipikat Hak Guna Usaha.

Berdasarkan latar belakang yang telah dihjelaskan diatas, tulisan ini akan membahas lebih dalam mengenai konsep dan pengaturan baru yang berkaitan dengan prosedur pembentukan peraturan pemerintah sebagaimana diatur dalam PP 18/2021 dan bagaimana kebijakan pemberian atas hak guna usaha yang diberikan di atas hak pengelolaan dalam perspektif Undang-Undang Pokok Agraria

\section{Metode Penelitian}

Penelitian ini adalah penelitian hukum normatif yang bertujuan untuk menganalisis Politik Hukum Pembentukan PP 18/2021, yang berkaitan dengan isu terkait HGU yang bisa diberikan di atas hak pengelolaan. Ketentuan tersebut bertentangan dengan UUPA yang mengharuskan HGU hanya bisa diberikan di atas tanah negara namun dalam ketentuan terbaru dapat diberi di atas HPL. Masalah ini dianggap akan menimbulkan konflik pertanahan semakin banyak kedepannya terutama pada bidang Persengketaan Tanah.

Penelitian normatif adalah tipe penelitian yang akan digunakan untuk penelitian, merupakan aturan dasar perundang-undangan yang berkaitan 
menjadi topik penelitian, yaitu kebijakan pemberian hak guna usaha di atas hak pengelolaan. Setelah itu pendekatan konseptual atau disebut (conceptual approach) dan Pendekatan perundangundangan (statute approach) yakni pendekatan yang akan digunakan. Menelaah dan mengkaji materi muatan peraturan meliputi Peraturan Pemerintah No. 18 tahun 2021, UUPA dan PP 24 tahun 1997 dan PP 9 tahun 1965 adalah Pendekatan perundang-undangan akan dilakukan. Menelaah lebih dalam isu hukum terkait dengan metode membangun konsep dengan diawali dengan pandangan dan pemikiran serta doktrin-doktrin yang sudah bertumbuh kembang di dalam suatu konsep ilmu hukum khususnya hukum pertanahan merupakan pendekatan konseptual yang akan dilakukan untuk mengkaji penelitian ini. ${ }^{16}$ Hukum pertanahan khususnya HGU di atas HPL dan hak menguasai tanah oleh negara menjadi doktrin yang akan ditunjuk menjadi fokus utama dalam kajian penelitian.

\section{Perkembangan Kebijakan Hak Guna Usaha Sebelum Berlakunya Peraturan Pemerintah Nomor 18 Tahun 2021}

Undang- Undang Nomor. 5 Tahun 1960 mengenai Peraturan Dasar Pokok- Pokok Agraria (UUPA) mengenal beragam jenis hak-hak atas tanah. ${ }^{17}$ Seiring perkembangan hukum pertanahan terdapat pula Hak Pengelolaan di Indonesia. secara yuridis di dalam UUPA, tidak terdapat penyebutan "Hak Pengelolaan" selaku salah satu hak atas tanah. UUPA hanya mengatakan sebutan "pengelolaan" saja. ${ }^{18}$

Hak Pengelolaan dikenal secara perdana melalui Peraturan Menteri No. 9/1965 mengenai Pelaksanaan Konversi Hak Menguasai Negara. Dalam perkembangannya, peraturan tersebut diganti dengan Peraturan Menteri Agraria Nomor. 9/1999 yang pada pokoknya mengatur mengenai badan hukum yang bisa memperoleh Hak Pengelolaan, seperti: BUMN, BUMD, Institusi Pemerintah Pusat

${ }^{16}$ Peter Mahmud Marzuki, Penelitian Hukum (Prenadamedia Group 2016).[177].

${ }^{17}$ Hak atas tanah menurut UUPA, meliputi: meliputi Hak Guna Usaha, Hak Milik, Hak Pakai serta Hak Guna Bangunan.

${ }^{18}$ Dalam Penjelasan Umum II angka 2 UUPA. 
dan Daerahm Badan Otorita, Badan Hukum lainnya yang ditunjuk Pemerintah serta PT. Persero.

Hak Pengelolaan ialah hak atas tanah yang dikuasai negara. Ia hanya dapat diberikan kepada badan hukum/pemerintah daerah serta diperuntukkan sebagai usaha sendiri/pihak ketiga. Selanjutnya, tanah yang dikuasai negara hendak diserahkan dengan suatu alas hak pengelolaan pada pihak ketiga yakni BUMN/BUMD jika tanah itu tidak hanya hendak dipergunakan guna kebutuhan pelaksanaan kewajibannya tetapi juga bagian-bagian dari tanah itu hendak dilimpahkan dengan sesuatu hak tertentu pada pihak ketiga, sehingga pada dasarnya hak pengelolaan memiliki sifat kumulatif. ${ }^{19}$ Pada akhirnya bisa disimpulkan kalau Hak Pengelolaan merupakan Hak Menguasai dari Negara yang wewenang penerapannya beberapa diberikan pada pemegang. Hak Pengelolaan ialah bidang serta bentuk suatu wewenang khusus yang terdapat pada Hak Menguasai dari Negara. ${ }^{20}$

Dikala saat sebelum terbitnya PP 18 Tahun 2021 bahkan sebelum adanya UUPA, terjalin perpecahan dua konsep hukum Pertanahan di Indonesia. Selain Hukum Agraria yang bersumber pada Hukum Perdata Barat, berlaku pula Hukum Agraria yang bersumber dari Hukum Adat. Sehingga ada tanah dengan hak-hak Barat maupun tanah dengan hak-hak Adat. ${ }^{21}$ Setelah itu semenjak diberlakukannya UUPA, hingga hak-hak yang masih berlaku atas tanah. ${ }^{22}$

Program konversi hak atas tanah bertujuan untuk unifikasi dan penyederhanaan hukum agraria nasional dalam hukum pertanahan, agar kedepan terdapat adanya jaminan kepastian hukum mengenai hak atas tanah. Dengan adanya konversi tersebut maka kelak tidak ada lagi hak- hak atas tanah produk hukum yang lama. Pada saat itu juga akan dimungkinkan terdapat hak atas tanah

\footnotetext{
${ }^{19}$ Seventina Monda Devita, 'Perkembangan Hak Pengelolaan Atas Tanah Sebelum Dan Sesudah Peraturan Pemerintah Nomor 18 Tahun 2021 Tentang Hak Pengelolaan, Hak Atas Tanah, Satuan Rumah Susun, Dan Pendaftaran Tanah' (2021) 2 Jurnal Hukum Lex Generalis.[873].

${ }^{20} \mathrm{ibid.}$

${ }^{21}$ ibid.[874].

${ }^{22}$ Bahwasannya hak- hak atas tanah yang ada dalam Pasal 16, ialah dikhususkan pada hakhak atas tanah pokok yaitu Hak Milik, Hak Guna Usaha, Hak Guna Bangunan serta Hak Pakai.
} 
dipastikan dapat berdiri di atas hak atas tanah. Sebagai salah satu contoh status apartemen ataupun bangunan rumah susun (Strata Title) yang berada di atas tanah HGB dan di atas tanah yang memiliki Hak Pengelolaan. Setiap pemilik unit satuan rumah pada apartemen/rumah susun yang sudah memiliki Sertifikat Hak Milik atas Satuan Rumah Susun (SHMSRS), maka SHMRS tersebut merupakan bukti atas kepemilikan bagian rumah susun beserta dengan tanahnya yang dimiliki serta dipakai dengan cara bergabung dengan pemilik yang lain dalam satu bagian bangunan gedung. ${ }^{23}$

Terjadinya HGU dari Permohonan atas pemberian HGU pada Kepala BPN RI dengan cara melalui kepala pertanahan Kab/Kota. Menindaklanjuti permintaan permohanan yang telah dilaporkan, selanjutnya maka dikeluarkannya atas SK pemberian hak atau SKPH dari kepala BPN RI diberikan atas dasar pelimpahan kewenangan guna memberikan sertipikat HGU. Keputusan presiden telah mengatur tentang aturan perihal syarat dan tata cara permohonan HGU. ${ }^{24}$ Namun mengenai tata cara pelaksaan aturan tentang pemberian sertpikat hak atas tanah (HAT) telah dituangkan dalam ketentuan. ${ }^{25}$

Kebijakan pemberian dari hak atas kerja sama hak guna usaha sebelum PP nomor 18 tahun 2021 berdasarkan persetujuan tertulis dari pemegang HPL, merupakan macam Kerjasama yang ditaungkan dalam perjanjian dan peralihan hak atas tanah guna infarstruktur pembangunan, contoh Sewa, pinjam pakai, rekan KSP, mitra BGS/BSG. mitra KSPI, (sebelum UU Perbendaharaan Negara (sebelum 2014)) dapat menggunakan sistem kerjasama menurut akad Perjanjian. ${ }^{26}$ Namun dalam PP 182021 mengisyaratkan bahwa seluruh atau sebagian tanah HPL untuk pemegang HPL dapat digunakan dan dimanfaatkan bagi pihaknya

${ }^{23}$ ibid.[69].

${ }^{24}$ Ni Putu Yunika Sulistiawati, ‘Pengaturan Pemberian Hak Guna Usaha Di Atas Tanah Hak Komunal Menurut Hukum Pertanahan Di Indonesia' (2020) 17 Jurnal Kerta Dyatmika.[42].

${ }_{25}^{2}$ PERMEN BPN RI 91999 mengenai Tata Cara Pembatalan dan Pemberian HAT Negara dan HPL jo.Peraturan Kepala BPN RI No 22013 mengenai Pelimpahan Kewenangan atas Pemberian HAT Dan Kegiatan Pendaftaran atas Tanah.

${ }^{26}$ Sekretariat DPP REI, 'Rancangan Peraturan Pemerintah Hak Pengelolaan Dan Hak Atas Tanah Berdasarkan Undang-Undang Cipta Kerja' (Sekretariat DPP REI, 2020) < https:/ / uu-ciptakerja. go.id/wp-content/uploads/2020/12/EXSUM_HPLHAT_USULAN-REI-071220-1607323829.7862. pdf $>$ accessed 11 February 2022. 
sendiri sepanjang diatur dalam Peraturan Pemerintahan yang dapat diberi hak atas tanah sesuai fungsi dan sifatnya sendiri. hal ini menjadi ketidakjelasan dari peruntukan hak pengelolaan itu sendiri bahwa sudah diberi hak oleh negara untuk mengusahakannya secara mandiri tetapi masih ada campur tangan pemerintah dalam hal ini memanfaatkan tanah negara.

\section{Kebijakan Pemberian Hak Guna Usaha Di Atas Hak Pengelolaan Dalam Perspektif Undang-Undang Pokok Agraria}

UUPA tidak mengklasifikasikan Hak Pengelolaan sebagai bagian dari hak atas tanah, tidak ditemui pengaturan mengenai hak tersebut dalam UUPA karena selama ini hanya bergantung dari Hak Menguasai dari Negara. Berakhirnya HGU maupun perpanjangan yang diberikan di atas Hak Pengelolaan diatur dengan ketentuan yang mengatur Hak Pengelolaan itu sendiri. Dalam implementasinya, Hak Pengelolaan mengalami beberapa perubahan yang cukup spesifik baik dari segi regulasi maupun praktiknya. Selain itu juga terdapat adanya perbedaan prespektif mengenai Pengelolaan dalam beberapa peraturan. Dalam UUPA, Pengelolaan diartikan sebagai kewenangan, sedangkan dalam Peraturan Menteri Pengelolaan diartikan sebagai hak atas tanah. Dalamimplementasi Hak Pengelolaan seringkali terjadi kekeliruan, pemegang hak pengelolaan seringkali mengalihkan kewajibannya kepada pihak ketiga padahal ia tidak berhak menjadi tuan tanah. Berdasarkan prinsip perjanjian berdasarkan itikad baik dan asas keseimbangan, seharusnya Notaris berperan penting dalam menentukan hak beserta kewajiban pemegang hak pengelolaan \& pihak ke-3. Sebab secara hukum pihak ke-3 hanya dapat diklasifikasikan sebagai pemegang hak atas tanah yang bersifat sementara karena ia hanyalah pihak yang menumpang. ${ }^{27}$

Sebagaimana konflik diantara UUPA dengan Hukum Sektoral yang diatur di berbagai sektor bidang sumber daya alam (Selanjutnya disebut PSDA). bahwa, UUPA lebih mengarah pada konservasi lingkungan atau peremajaan

\footnotetext{
${ }^{27}$ Sulasi Rongiyati, 'Pemanfaatan Hak Pengelolaan Atas Tanah Oleh Pihak Ketiga' (2014) 5 Jurnal Negara Hukum.[78].
} 
lingkungan, lebih pro rakyat, dan juga membetulkan serta mensegani kehadiran suku masyarakat adat. Kebalikannya UU bidang PSDA menekankan syarat akan kerusakan lingkungan (pendayagunaan), sangat jelas membela pada asset (penyandang dana ataupun penanam modal). penilaian penyebab terjadinya konflik norma itu sebab UUPA dan UU bidang PSDA tidak mempunyai tujuan yang selaras. Analogi konsep itu terjalin karena UUPA sendiri dalam perannya sebagai acuan untuk dibuatnya UU PSDA dalam hal ini PP 18 Tahun 2021 tidak dijadikan rujukan dalam pembuatan klasifikasi UU Sektoral PSDA. ${ }^{28}$

Pada kesempatan kali ini menghasilkan konsepsi kalau hak guna usaha adalah alas hak atas tanah dari tanah Negara. Kata "dikuasai langsung oleh Negara” yang artinya bahwa hak atas tanah itu merupakan tanah Negara. Peraturan Pemerintah Nomor 24 Tahun 1997 mengenai Pendaftaran Tanah, pula merumuskan pada Pasal 1 Angka 3, yakni “Tanah Negara ataupun tanah yang dikuasai langsung oleh Negara adalah tanah yang tidak dipunyai dengan sesuatu hak atas tanah" ${ }^{29}$

Dalam hal perpanjangan HGU di atas Hak Pengelolaan lebih terikat dengan politik hak atas tanah dari Penguasa Pusat lewat Kementerian, Departemennya maupun Pemerintah Daerah dalam kewenangannya. Pendaftaran hak atas tanah yang dilakukan oleh pemegang izin HGU yang memberi keterangan bahwa alat pembuktian sempurna di pengadilan yang kuat dan legalnya tiap perpindahan, pembebanan serta hapusnya hak itu setiap berakhirnya periode masa HGU, hingga cara beralihnya jadi Hak Pengelolaan yang terdapat ketentuan hukum pertanahan dituturkan HGU di Atas Hak pengelolaan, berpindah sebagai Hak Pengelolaan, bukan lagi selaku HGU. HGU pada dasarnya telah diatur dalam UUPA yang waktu waktunya hadapi pergantian dari konsep dasar serta ketentuan pada UUPA. Pergantian waktu tersebut erat kaitannya dengan upaya peningkatan investasi dan upaya menarik penanam modal pada aspek pertanian mapun perkebunan.

${ }^{28}$ Cindy Engeline Watung, 'Tinjauan Yuridis Mengenai Perpanjangan Hak Guna Usaha Dengan Pemerintah Sebagai Pemilik Hak Pengelolaan’ (2021) 9 Jurnal Lex Privatum.[46].

${ }_{29}$ Hak Pengelolaan merupakan hak menguasai dari negara atas tanah. Bukan hanya menggambarkan hak atas tanah sedemikian itu pula yang dituturkan dalam Pasal 4 bagian (1) jo. Pasal 16 bagian (1) UUPA. Hak Pengelolaan bertumbuh serta berkembang dari gerak politik pertanahan nasional yang bersumber dari "Hak Menguasai dari Negara". 
HGU pada prinsipnya dapat diberikan di atas hak pengelolaan meruapakan sebegai bentuk pelimpahan dari konsep hak menguasai negara dengan berpedoman dengan mengikuti RTRW (Rencana Tata Ruang dan Wilayah) diperuntukan untuk usaha pertanian perkebunan, peternakan dan perikanan, namun aturan yang terdapat pada pasal 21 PP 182021 yang mengharuskan pemberian HGU hanya dapat diberikan pada tanah negara dan tanah hak pengelolaan. Aturan tersebut bertentangan apa yang di atur sejak dahulu ada pada ketentuan Pasal 28 UUPA yakni HGU, konsep HGU yakni mengusahakan tanah yang berasal dari dikuasai langsung oleh negara bukan tanah yang telah diusahakan oleh pemegang akta sertipikat hak pengelolaan yang berupa perkebunan, pertanian atau periknanan.

Menurut Teori hierarki yang dijadikan penulis suatu fokus Maka jika dilihat dari teori secara hirarkis produk hukum dalam hal ini merupakan turunan dari UUCK yakni berbentuk Peraturan Pemerintah (PP 18 Tahun 2021) yang dibentuk oleh pemerintah juga terdapat hirarki di undang-undang, dari isu tersebut maka berlakulah asas yang disebut lex superiori derogat legi inferiori. ${ }^{30}$ Sistem perundangundangan tersebut apabila tidak mentaati asas akan menimbulkan ketidak pastian hukum dan ketidak tertiban adminitrasi. Bukan hanya itu bahkan bisa saja sampai terjadi kesimpangsiuran dan kekacauan perundang-undangan. ${ }^{31}$

Isu ketidakpastian hukum diatas apabila ada pihak yang dirugian atas peraturan perundang-undangan tersebut bisa dipastikan pihak tersebut melayangkan permohonan karena merasakan dirugikan yakni potensi adanya pengajuan uji materi (judicial revierw) pada isu ini maka produk hukum peraturan pemerintah dimana materinya tidak sesuai dengan undang-undang, dapat dilakukan uji materi (judicial review) oleh MA. ${ }^{32}$ Mahkamah agung dalam hal ini apabila ternyata tidak sesuai muatan konsep materi peraturan perundangundangan yang telah dinilai lebih tinggi, MA berwenang dapat melakukan

\footnotetext{
${ }^{30}$ Memilki makna peraturan yang lebih rendah dikesampingkan oleh peraturan yang lebih tingg.

${ }^{31}$ Sayid M Rifqi Noval dan Aries Nur Utomo, 'Tinjauan Yuridis Produk Hukum Lembaga Independen Negara Yang Tidak Sesuai Dengan Peraturan Perundang-Undangan Yang Lebih Tinggi Berdasarkan Teori Hierarki Perundang-Undangan' (2019) 1 Jurnal Pemuliaan Hukum.[35].

32 ibid.
} 
uji materi (judicial review) terkait produk hukum tersebut guna mendapatkan kepastian hukum guna apabila ada pihak yang akan mengajukan permohonan HGU dan yang telah mendapat sertipikat HGU tidak dirugikan.

\section{Kesimpulan}

Sebagaimana hak atas tanah yang diatur di dalam UUPA tidak ditemukan ketentuan mengenai Hak Pengelolaan sebagai salah satu hak atas tanah. kebijakan pemberian dari hak atas kerja sama hak guna usaha sebelum PP nomor 18 tahun 2021 berdasarkan persetujuan tertulis dari pemegang HPL, Namun dalam PP 18 2021 mengisyaratkan bahwa seluruh atau sebagian tanah HPL untuk pemegang HPL dapat digunakan dan dimanfaatkan bagi pihaknya sendiri sepanjang diatur dalam Peraturan Pemerintahan yang dapat diberi hak atas tanah sesuai fungsi dan sifatnya sendiri.

HGU pada prinsipnya dapat diberikan di atas hak pengelolaan meruapakan sebegai bentuk pelimpahan darikonsephak menguasainegara dengan berpedoman dengan mengikuti RTRW (Rencana Tata Ruang dan Wilayah) diperuntukan untuk usaha pertanian perkebunan, peternakan dan perikanan, namun aturan yang terdapat pada pasal 21 PP 182021 yang mengharuskan pemberian HGU hanya dapat diberikan pada tanah negara dan tanah hak pengelolaan. Aturan tersebut bertentangan apa yang di atur sejak dahulu ada pada ketentuan Pasal 28 UUPA yakni HGU, konsep HGU yakni mengusahakan tanah yang berasal dari dikuasai langsung oleh negara bukan tanah yang telah diusahakan oleh pemegang akta sertipikat hak pengelolaan yang berupa perkebunan, pertanian atau perikanan, sehingga berlaku asas lex superiori derogat legi inferiori dan akibatnya peraturan perundang-undangan tersebut menimbulkan ketidakpastian hukum yang berpotensi uji materi oleh Mahkamah Agung.

\section{Daftar Bacaan}

\section{Buku}

Md M, Politik Hukum Di Indonesia (Raja Grafindo Persada 2011). 
Peter Mahmud Marzuki, Penelitian Hukum (Prenadamedia Group 2016).

Sri Hajati et al, Politik Hukum Pertanahan Indonesia (Airlangga University Press 2021).

\section{Jurnal}

Cindy Engeline Watung, 'Tinjauan Yuridis Mengenai Perpanjangan Hak Guna Usaha Dengan Pemerintah Sebagai Pemilik Hak Pengelolaan' (2021) 9 Jurnal Lex Privatum.

Ni Putu Yunika Sulistiawati, 'Pengaturan Pemberian Hak Guna Usaha Di Atas Tanah Hak Komunal Menurut Hukum Pertanahan Di Indonesia' (2020) 17 Jurnal Kerta Dyatmika.

Sayid M Rifqi Noval dan Aries Nur Utomo, 'Tinjauan Yuridis Produk Hukum Lembaga Independen Negara Yang Tidak Sesuai Dengan Peraturan Perundang-Undangan Yang Lebih Tinggi Berdasarkan Teori Hierarki Perundang-Undangan' (2019) 1 Jurnal Pemuliaan Hukum.

Seventina Monda Devita, 'Perkembangan Hak Pengelolaan Atas Tanah Sebelum Dan Sesudah Peraturan Pemerintah Nomor 18 Tahun 2021 Tentang Hak Pengelolaan, Hak Atas Tanah, Satuan Rumah Susun, Dan Pendaftaran Tanah' (2021) 2 Jurnal Hukum Lex Generalis.

Sulasi Rongiyati, 'Pemanfaatan Hak Pengelolaan Atas Tanah Oleh Pihak Ketiga' (2014) 5 Jurnal Negara Hukum.

Triadi Kurniawan, 'Jurnal Fakultas Hukum Universitas Tulang Bawang' (2020) 18 Jurnal Keadilan Fakultas Hukum Universitas Tulang Bawang.

\section{Laman}

Sekretariat DPP REI, 'Rancangan Peraturan Pemerintah Hak Pengelolaan Dan Hak Atas Tanah Berdasarkan Undang-Undang Cipta Kerja' (Sekretariat DPP REI, 2020) <https://uu-ciptakerja.go.id/wp-content/uploads/2020/12/ EXSUM_HPLHAT_USULAN-REI-071220-1607323829.7862.pdf> accessed 11 February 2022.

\section{Perundang-undangan}

Undang-Undang Dasar Negara Republik Indonesia Tahun 1945.

Undang-Undang Nomor 5 Tahun 1960 Tentang Peraturan Dasar Pokok-Pokok Agraria (Lembaran Negara Republik Indonesia Tahun 1960 Nomor 104, 
Tambahan Lembaran Negara Republik Indonesia Nomor 2043).

Undang-Undang Nomor 11 Tahun 2020 Tentang Cipta Kerja.

Peraturan Pemerintah Republik Indonesia Nomor 40 Tahun 1996 Tentang Hak Guna Usaha, Hak Guna Bangunan Dan Hak Pakai Atas Tanah (Lembaran Negara Republik Indonesia Tahun 1996 Nomor 58, Tambahan Lembaran Negara Republik Indonesia Tahun 1996 Nomor 3643).

Peraturan Pemerintah Nomor 24 Tahun 1997 Mengenai Pendaftaran Tanah.

Peraturan Pemerintah Nomor 18 Tahun 2021 Tentang Hak Pengelolaan, Hak Atas Tanah, Satuan Rumah Susun Serta Pendaftaran Tanah.

Peraturan Menteri Agraria Nomor 9 Tahun 1965 Tentang Pelaksanaan Konversi Hak Menguasai Negara.

Peraturan Menteri Agraria No. 9 Tahun 1999 Tentang Tata Cara Pemberian Dan Pembatalan Hak Atas Tanah Negara Dan Hak Pengelolaan.

Peraturan Menteri Dalam Negeri Nomor 1 Tahun 1977 Tentang Tata Cara Permohonan Dan Penyelesaian Pemberian Hak Atas Bagian-Bagian Tanah Hak Pengelolaan Serta Pendaftarannya.

How to cite: Aditya Darmawan Zakaria, 'Kebijakan Pemberian Hak Guna Usaha Di Atas Hak Pengelolaan Dalam Perspektif Undang-Undang Pokok Agraria' (2022) Vol. 5 No. 1 Notaire. 
16 | Aditya Darmawan: Kebijakan Pemberian Hak...

--Halaman ini sengaja dikosongkan-- 